\title{
АНАЛІЗ ПРОБЛЕМИ ОПТИМІЗАЦІЇ КРИТЕРІЇВ ОЦІНКИ СТУПЕНЯ ПРИДАТНОСТІ ЗОВНІШНІХ ПІЛОТІВ БЕЗПІЛОТНИХ АВІАЦІЙНИХ КОМПЛЕКСІВ ДО РОБОТИ ЗА ФАХОМ ПІД ЧАС ПРОВЕДЕННЯ ЛІКАРСЬКО-ЛЬОТНОЇ ЕКСПЕРТИЗИ
}

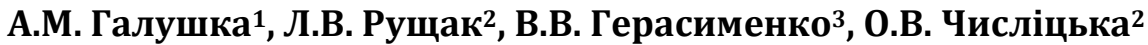 \\ ${ }^{1}$ Командування Медичних сил Збройних Сил Украӥни, м. Київ, Украӥна \\ гУкраїнська військово-медична академія, м. Київ, Україна \\ ${ }^{3}$ Національний університет оборони України імені Івана Черняховського, м. Київ, Україна
}

Вступ. Важливе місце у надійності зовнішнього пілота БпАК належить психофізіологічній підготовці, оскільки при експлуатації сучасної техніки гостро постає питання психофізіологічного бар'єру, причини якого лежать у психофізіологічних спроможностях та факторі часу, який виділяється на прийняття рішення. Вище зазначене вказує на необхідність пошуку нових методичних підходів до адекватного використання людського потенціалу враховуючи специфіку праці зовнішнього пілота БпАК.

Мета. Аналіз проблеми оптимізації критеріїв оцінки ступеню придатності зовнішніх пілотів безпілотних авіаційних комплексів до роботи за фахом під час проведення лікарсько-льотної експертизи. niдxодy.

Матеріали та методи. Бібліосемантичний, історичний, структурно-логічний та системного

Результати. В Україні до цих пір використання БпАК мало обмежений характер. На жаль, досі не існує державної програми розробки та експлуатації БпАК, тому немає загальної стратегії розвитку безпілотної авіації, виникає певна плутанина у технічній та дозвільній документації, термінології, невирішеними залишаються проблеми підготовки та добору операторів. Складність застосовуваних БпАК та різноманітність завдань, що реалізовуються з їх допомогою, визначають максимально широкий спектр вимог до професійної підготовленості операторів, які здійснюють керування такими авіаційними комплексами. Практика показує, що забезпечення надійності діяльності операторів БпАК та успішності виконання ними завдань за призначенням має реалізовуватися починаючи з етапу професійного відбору кандидатів на навчання за відповідною спеціальністю. Саме якісний науково обгрунтований та методично забезпечений професійний відбір дасть змогу уникнути значних фінансових і часових витрат на підготовку професійно не придатних фахівців, зменшити втрати високовартісних БпАК і не допустити створення прецедентів небезпек від непрофесійної експлуатації наведеної техніки. Усе зазначене вище актуалізує необхідність якісного здійснення професійного відбору кандидатів на посади операторів (зовнішніх пілотів) безпілотних авіаційних комплексів тактичних класів для потреб ЗС України, НГу та інших силових структур нашої країни.

Важливою умовою профвідбору та аналізу ефективності спеціальної підготовки $\epsilon$ вивчення психологічної готовності, а саме: індивідуально-психологічних та психофізіологічних особливостей операторів БпАК. Таким чином, одним з першорядних завдань в підготовці фахівців даної галузі є розробка діагностичного інструментарію вивчення готовності до здійснення професійної діяльності.

Висновки. Незважаючи на досліжження окремих питань, проблема комплексної оцінки, з позиції системного підходу до професійного здоров'я, у тому числі, умов, причин і економічних наслідків захворюваності експлуатантів, досліджена недостатньо. Виявлені в результаті системно-структурного аналізу чинники, умови і причини, що визначають професійне здоров'я зовнішнього пілота, дозволять скласти комплексне уявлення про його професійне здоров'я, що вкрай необхідно для розробки комплексу заходів з оптимізації медичного забезпечення та збереження здоров'я зовнішніх пілотів. Враховуючи те, що у Збройних Силах України з початку 2020 року триває робота стосовно набуття доктринальної взаємосумісності з державами-членами НАТО, актуальним напрямом є розроблення критеріїв оцінки ступеню придатності операторів безпілотних авіаційних комплексів до роботи за фахом під час проведення лікарсько-льотної експертизи.

Ключові слова: безпілотний авіаційний комплекс, зовнішній пілот, професійна придатність.

Вступ. На сьогоднішній день питання застосування перебуванням середовищі досліджувати процес взаємодії людини і техніки, оскільки пріоритетна роль в даній системі, все ж таки, належить людині - інтеграція управління. Відтак, «людський фактор» залишається основним, а значні фізичні та інформаційні навантаження потребують детального вивчення впливу як зовнішніх факторів, що відбиваються на функціональному стані людини i, тим самим 
формують її працездатність, так і комплексу внутрішніх факторів $[9,10]$.

Сучасні уявлення про систему «людинамашина» [46] вказують на домінуючу роль людини, яка підкріплена технологічними рішеннями, умовами професійної діяльності і пристосована до психофізіологічних характеристик. А відтак, основна роль в даній системі, значною мірою, належить ергономічності робочого простору [41].

Важливе місце у надійності зовнішнього пілота БпАК належить психофізіологічній підготовці, оскільки при експлуатації сучасної техніки гостро постає питання психофізіологічного бар'єру, причини якого лежать у психофізіологічних спроможностях та факторі часу, який виділяється на прийняття рішення[45].

На теперішньому етапі становлення вітчизняної безпілотної авіації, в разі необхідності, відповідні роботи можуть бути виконані іншими авіаційними спеціалістами (авіаційним техніком 3 планера та двигунів, авіаційним техніком з радіоустаткування) після відповідного підвищення кваліфікації [43-46]. Хоча втрата БПЛА не пов'язана із загибеллю пілота, при використанні БПЛА не мають значення перенавантаження, робота оператора керування БПЛА пов'язана з нервово-емоційним напруженням при виконанні складних завдань. Наприклад, оператори, які проводили бойові дії із застосуванням летальної зброї, піддавались значному психологічному навантаженню, яке викликало посттравматичний синдром. Також має значення розуміння оператором суттєвої вартості БПЛА. Так у сучасних американських БПЛА вартість 1кг планера становить 3300 доларів США, вартість цільового навантаження 17260 доларів США [1-21, 23, 30].

Все вище зазначене вказує на необхідність пошуку нових методичних підходів до адекватного використання людського потенціалу враховуючи специфіку праці зовнішнього пілота БпАК.

Мета. Аналіз проблеми оптимізації критеріїв оцінки ступеню придатності зовнішніх пілотів безпілотних авіаційних комплексів до роботи за фахом під час проведення лікарсько-льотної експертизи.

Матеріали та методи дослідження. Бібліосемантичний, історичний, структурнологічний та системного підходу. Використано доступні джерела літератури відповідно до мети дослідження за останні 15 років.

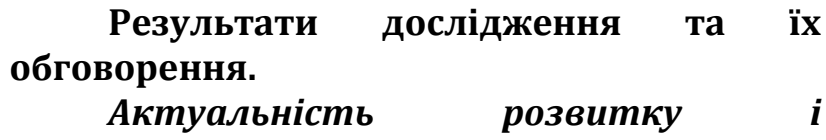
застосування безпілотних авіаційних комплексів у світі і в Україні. Поштовхом до розвитку безпілотної авіації у світі стало успішне та широке застосування БпАК арміями США та Ізраїлю у ході операцій у Перській Затоці, Югославії, арабоізраїльського конфлікту. В теперішній час розвиток БпАК переживає підйом. Створюється широка номенклатура машин від стратегічних до міні БпЛА, що розраховані на індивідуальне застосування військовослужбовцем на полі бою [33-36]. Конструюються пропелерні, реактивні та гвинтокрилі апарати різноманітного призначення - від розвідувальних до винищувальних і ударних варіантів. Зазвичай оснащені потужною електронікою, розвідувальною апаратурою, потужним екрануванням від перешкод [38]. Мають розміри від компактних до таких, що співставні з повномірним повітряним судном. Сучасні БпАК виконують широкий обсяг задач: повітряна розвідка загального та спеціального призначення; радіоелектронна боротьба, включаючи електронну розвідку, радіоелектронне придушення радіоелектронних засобів противника, насичення зон ППо псевдо цілями; цілевказання системам зброї 3 лазерним наведенням; корегування артилерійського вогню; ураження наземних цілей, включаючи ураження РЛС; забезпечення радіорелейного зв'язку та ін[40-44].

Умовне групування за класифікацією, яка прийнята в країнах-членах НАТО та викладена у Концепції оснащення військових частин та підрозділів ЗС України безпілотними авіаційними комплексами на період до 2025 року. Визначені такі класи БпАК [40]:

I клас "Легкі" (мікро (тактичні) БпЛА БпАК - micro; міні (тактичні поля бою) - mini; малі (тактичні) - small);

II клас “Середні” (tactical);

III клас "Важкі" (оперативні БпЛА БпАК середньої висоти, довгої тривалості (medium altitude long endurance) - MALE; стратегічні БПЛА БПАК великої висоти, довгої тривалості (high altitude long endurance) - HALE).

Використання БпАК дозволило суттєво знизити втрати живої сили і дороговартісної техніки під час вирішення бойових завдань i одночасно суттєво підвищити ефективність 
застосування високоточних та звичайних засобів ураження. Це підтверджується, зокрема, досвідом бойових дій на Сході України та в Сирії [33-38].

3 урахуванням досвіду останніх локальних війн і збройних конфліктів (Близький Схід, 1982-2008 рр.; Балкани,
1999 р.; Афганістан, 2001-2008 рр.; Кавказ, 1994-2008 рр.), і насамперед, АТО (ООС), особливу увагу слід приділити питанню застосування БпАК різних типів. Динаміка зростання частки БпЛА, на прикладі розвідувальних, наведена на рис 1.

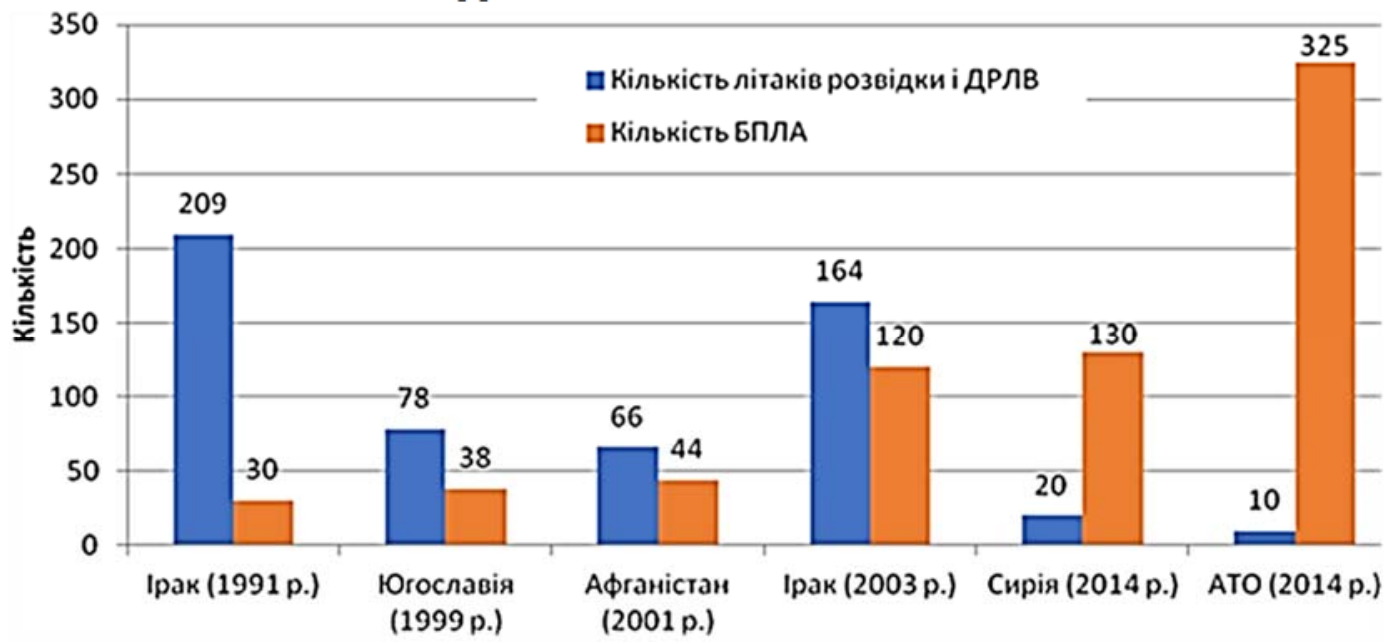

Рисунок1. Порівняння кількості БпЛА з кількістю літаків розвідки, ДРЛВ і управління, що застосовувалися у локальних війнах і збройних конфліктах [33]

Як наведено на рис. 1. в умовах економічних складнощів та обмеженого фінансування 3С України, саме масоване застосування БПЛА дозволяє вирішувати завдання розвідки на належному рівні. Інший важливий ефект від такого підходу збереження життя льотного складу пілотованої авіації і дороговартісної авіаційної техніки за одночасного зниження експлуатаційних витрат [33].

В Україні до сих пір використання БпАК мало обмежений характер. БпЛА Ту-143 у складі комплексу повітряної розвідки ВР-3 «Рейс», який є на озброєнні збройних сил України (ЗСУ), $є$ розробкою початку $70-х$ років, розроблявся та вироблявся на території РФ, на наш час $є$ застарілою технікою та не відповідає сучасним вимогам [36]. Потреба ЗСУ у тактичних розвідувальних БПЛА оцінюється у орієнтовно у 400 шт. Нажаль, досі не існує державної програми розробки та експлуатації БПЛА, тому немає загальної стратегії розвитку безпілотної авіації, виникає певна плутанина у технічній та дозвільній документації, термінології, невирішеними залишаються проблеми підготовки та добору операторів. Окремі виробники вирішують ці питання на власний розсуд [38]. Наведемо декілька прикладів перспективних вітчизняних розробок [40-44]. Багатоцільовий БпАК Р-100, що створений українськими спеціалістами для ЗСУ, може застосовуватись для військових та

цивільних потреб використовується у складі комплексної системи забезпечення охорони державного кордону), він має масу біля 15 кг, дальність польоту до 100 км, час безперервного перебування в повітрі до 6 годин. БПАК MRE «Стрепет-L» у військові сфері застосовується задля розвідки, визначення координат цілей, контролю після нанесення ударів, супроводження колон техніки, він має розмах крила 4,2 м, може нести до 35 кг цільового навантаження та перебувати в повітрі до 6 годин. БпАК «Фурія» А-1 С знаходиться на озброєнні Національної гвардії, в перспективі надійде до ЗС. В кожному комплексі - наземна станція керування, три БПЛА. Комплекс обслуговують від двох до чотирьох осіб, час розгортання комплексу біля 4 хвилин. Старт БПЛА здійснюється з катапульти, посадка за допомогою парашута. Пункт керування оснащений двома моніторами. Перший монітор призначений для слідкування за геоінформаційною системою з прив'язкою до координат та GPS - позицій планера, другий для ведення спостереження через оптичну камеру, зображення передається в масштабі реального часу. БПЛА має дальність польоту до $100 \kappa м$, перебування в повітрі до 4 годин. Вартість БпАК від 10 до 22 тисяч доларів США. Навчання операторів проводиться на базі виробника. БПЛА контейнерного старту багаторазового використання «Сокіл-2» 
призначений для ведення розвідки в режимі реального часу 3 можливістю запам'ятовування та перегляду відеоінформації, визначення координат цілей 3 передачею інформації на командний пункт. БПЛА входить до складу комплексу розвідки, який встановлюється на бойовій машині типу БМП або БТР. «Сокіл-2» має дальність польоту до $20 \kappa м$, час польоту 1,5-2 години, масу 5кг [47].

Особливості праці оператора БпАК. Застосування БпАК відбувається під впливом таких основних груп факторів: особливостей умов ведення збройної боротьби, науковотехнічного прогресу, психологічного та воєнно-економічного чинників [39]. На застосування БпАК найсуттєвіше впливають зміни характеру збройної боротьби та складні фізико-географічні умови районів ведення бойових дій. Складний рельєф, кліматичні та метеорологічні умови районів конфліктів, особливості фізико-географічних умов висувають додаткові вимоги як до БпАК, так і до гігієнічних умов праці оператора (зовнішнього пілота). у психологічному факторі основну роль відіграють особливості спільного застосування для виконання поставлених задач людини і техніки [1-21]. Так важливу роль відіграє функціональне призначення БпАК. Для виконання широкого обсягу задач застосовують такі способи керування:

ручне управління оператором (дистанційне пілотування) 3 дистанційного пульта керування в межах оптичного спостереження або ж за інформацією, що надходить з відеокамери переднього огляду;

автоматичне керування за допомогою бортового програмного устаткування, що забезпечує можливість повного автономного польоту БпАК за заданою траєкторією, на заданій висоті, із заданою швидкістю;

напівавтоматичне

керування

(дистанційне керування) - політ здійснюється автоматично без втручання людини за допомогою автопілота за початково заданими параметрами, але оператор може вносити зміни в маршрут в інтерактивному режимі, тобто дозволяє впливати на політ 3 наземної станції.

Останні два способи не ставлять високих вимог до підготовки оператора та дозволяють забезпечити надійну експлуатацію БпАК.

Складність застосовуваних БпАК та різноманітність завдань, що реалізовуються 3 ï допомогою, визначають максимально широкий спектр вимог до професійної підготовленості операторів, які здійснюють керування такими авіаційними комплексами [22-23]. Практика показує, що забезпечення надійності діяльності операторів БпАК та успішності виконання ними завдань за призначенням має реалізовуватися починаючи 3 етапу професійного відбору кандидатів на навчання за відповідною спеціальністю. Саме якісний науково обгрунтований та методично забезпечений професійний відбір дасть змогу уникнути значних фінансових і часових витрат на підготовку професійно не придатних фахівців, зменшити втрати високовартісних БпАК і не допустити створення прецедентів небезпек від непрофесійної експлуатації наведеної техніки [32, 37, 43-36]. Усе зазначене вище актуалізує необхідність якісного здійснення професійного відбору кандидатів на посади операторів (зовнішніх пілотів) безпілотних авіаційних комплексів тактичних класів для потреб ЗС України, НГУ та інших силових структур нашої країни. Вирішення цього складного науково прикладного завдання можливе на основі використання сучасних надбань теорії професійної придатності фахівців ризиконебезпечних видів діяльності та концепцій їх професійного відбору, вивчення досвіду практичного застосування БпАК, проведення професіографічного аналізу та встановлення психологічних особливостей діяльності операторів, які їх експлуатують, а також виявлення шляхів удосконалення методичної складової здійснення процедур професійного (у тому числі психологічного) відбору.

Важливими $\epsilon$ передумови процесу симбіотичного застосування БпАК і БАС. До таких належать:

1. Нормативно-правова;

2. Матеріально-технічна;

3. Ресурсна;

4. Безпекова (захищеність каналів передачі інформації);

5. Професіографічна (стан здоров'я, психофізіологічний відбір, освіта, досвід, участь у бойових діях оператора (пілота), безпека професійного середовища).

В нових умовах вимоги, що застосовуються до зовнішніх пілотів БпАК, потребують переосмислення та впровадження.

Виходячи із зазначеного вище, необхідною передумовою симбіотичного 
застосування БпАК є виявлення чинників, що впливають на експлуатантів до- та під час виконання бойового завдання (рис 2).

Для практичного застосування зазначених особливостей професійної діяльності експлуатантів необхідно розв'язати низку питань: якість сприйняття сигналів;

термін чіткої роботи в режимі навантаження під час виконання польотних завдань;

адекватна передача інформації;

вплив мікро- та макроклімату на виконання завдання.

розвиток втоми;

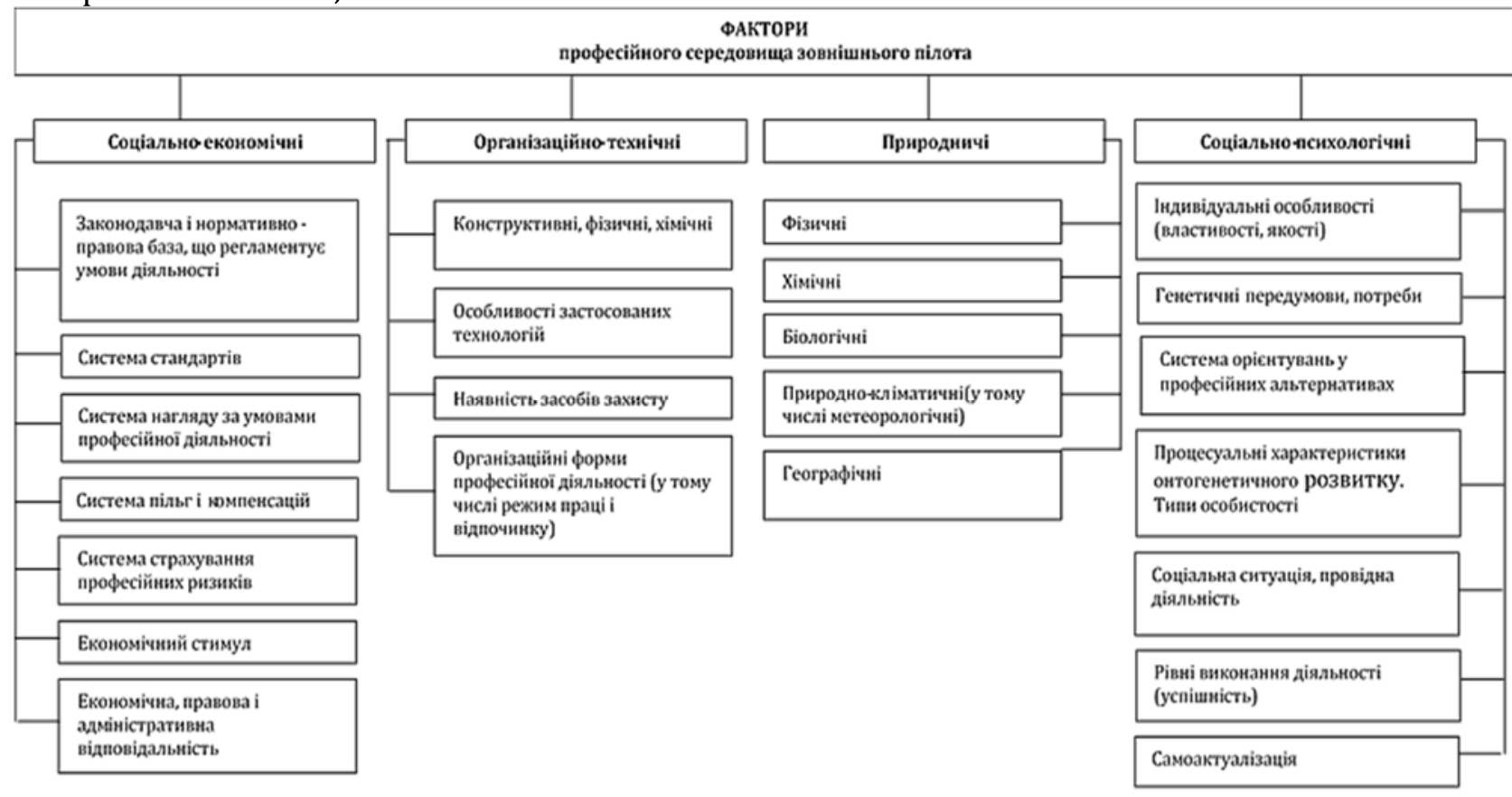

Рисунок 2. Структурно-логічна схема факторів професійного середовища зовнішнього пілота

Існуючі підходи до професійного відбору зовнішніх пілотів БпАК. Існуючі на сьогодні підходи до комплектування професійними кадрами не виправдовують себе, оскільки високий рівень відповідальності за керування новим видом техніки вимагає не тільки знань, вмінь і навичок, але й спеціальної психофізіологічної підготовки для ефективного вирішення поставлених задач [43-45]. У зв'язку з чим, необхідно, щоб профвідбором займались підготовлені фахівці в галузі керування БпАК, що пройшли цільову підготовку в даному напрямі. Необхідним $\epsilon$ розуміння сутності ефективності низки компонентів, таких як профвідбір та фактори, що впливають на якість професійної діяльності оператора (зовнішнього пілота) [46, 47].

Саме нові науково-методичні i матеріально технічні умови сьогодні підсилюють роль професійно-службової активності фахівців профвідбору та їх компетентності. Грамотно розроблені i застосовані методики, та інтерпретовані результати профвідбору запорука успішності підготовки фахівців з управління БпАК.
Важливою умовою профвідбору та аналізу ефективності спеціальної підготовки $€$ вивчення психологічної готовності, а саме: індивідуально-психологічних та психофізіологічних особливостей операторів БпАК. Таким чином, одним з першорядних завдань в підготовці фахівців даної галузі $\epsilon$ розробка діагностичного інструментарію вивчення готовності до здійснення професійної діяльності.

Хоча аналіз аварійності показує, що відмови силової установки були причиною $37 \%$ аварій, системи управління - 26\%, помилки операторів - 17\%, втрата зв'язку $11 \%$, інші причини - 9\% [38], найбільш уразливою ланкою при виникненні позаштатної ситуації або аварії $\epsilon$ безпосередньо управління БПЛА. Помилка тут визначається як невиконання поставленого завдання, що пов'язано 3 ушкодженням устаткування, програмного забезпечення БпАК, порушенням технологічного процесу та ін. Надійність оператора БпАК визначається здатністю виконувати в повному обсязі поставлені завдання. В такому випадку профвідбір для операторів БпАК визначається 
як дослідження, що засновано на чітких якісних та кількісних оцінках, що дозволяють не тільки виявити, але й виміряти притаманні людині якості 3 метою їх порівняння 3 нормативами, визначаючими придатність до професійної діяльності $[44,46]$.

Досвід експлуатації БпАК показує, що найефективнішою для управління та прийняття рішень у наземному пункті керування є команда з трьох осіб [32, 43-47]: 1) оператор керування польотом БпАК; 2) оператор бойових систем (його задачі знаходження, ідентифікація цілі, прийняття рішення про застосування зброї); 3) оператор інтелектуальних систем, який має досвід керування польотом БпАК та володіє системами інтелектуальної підтримки. Ця команда зі своїми робочими місцями об'єднана в локальну мережу і знаходиться в одному операторському приміщенні.

Окремо можна виділити командирів розрахунків, які виконують керівництво розрахунком, планування польотних завдань, здійснюють взаємодію 3 командуванням, організацію підготовки БпАК до вильоту, керівництво діями підлеглих при виникненні аварійних ситуацій на борту і т.п. Оператори, які працюють в стаціонарних або мобільних пунктах керування БпАК, потребують професійного добору внаслідок складності поставлених перед ними задач [34, 40, 41, 47].

При проведенні профвідбору необхідно враховувати, як рівень освіти, досвіду i підготовки, так і ступінь відповідності індивідуальних психофізіологічних якостей даної людини до здійснення керування БпАК. Крім того необхідно розглядати різні аспекти сумісності людини і техніки:

обов'язкове

врахування

антропометричних даних, можливості огляду зовнішнього простору, пози оператора в процесі керування БпАК - так звана, антропометрична сумісність;

визначення чутливості організму до температурного режиму, освітленості, механічним і акустичним коливанням, електромагнітному випромінюванню, та іншим гігієнічним чинникам робочого середовища. Відповідність органів керування БпАК з оптимальними можливостями людини по відношенню до застосованих зусиль, застосованої потужності, швидкості і точності рухів - енергетичній сумісності;

характеризуючи органи чуттів та можливість одночасно стежити за показаннями індикаторів польоту, навігаційних приладів, візуальних даних, та корегувати їх параметри із врахуванням особливостей польотного завдання інформаційну сумісність.

Відомо, що зовнішні пілоти контролюють обстановку навколо віддаленого БпАК тільки через свій монітор за вхідним відеосигналом і звуковим супроводом, які на великих відстанях доходять із запізненням до 1 сек, тому вкрай важливо при відборі і підготовці зовнішніх пілотів в авіації, операторів наземних, надводних мобільних комплексів мати контингент 3 високим рівнем реакції та зорово-моторної координації [15-18].

Світова практика говорить про неможливість допуску до професійної діяльності оператора БпАК осіб, які мають такі захворювання [24-31]:

- $\quad$ захворювання ЦНС, що супроводжуються розладами координації, руховими, інтелектуальними або когнітивними порушеннями;

- епілепсія та епілептичний синдром;

- катаплексія, нарколепсія;

- психічні захворювання;

- туберкульоз;

- наркоманія, токсикоманія, алкоголізм;

- захворювання печінки - гепатит, цироз;

- $\quad$ високий ступінь міопії, ускладнена короткозорість;

- катаракта;

- глаукома;

- дегенеративні захворювання сітківки ока;

- $\quad$ прогресуючі захворювання ендокринної системи;

- $\quad$ злоякісні новоутворення;

- $\quad$ хронічні серцево-судинні захворювання;

- $\quad$ прогресуючі захворювання крові і

кровотворних органів;

- ревматизм

- $\quad$ порушення функцій вестибулярного апарату, ністагм.

Діючий Класифікатор професій - ДК 003:2010 містить назву професії «оператор наземних засобів керування безпілотним літальним апаратом» (код 3144) [37, 38], що є достатнім при використанні малорозмірних БпЛА. За умов використання більш складних БпАК будуть необхідні інші спеціалісти оператор бортового радіоелектронного обладнання, технік по обслуговуванню БпАК та ін. В зв'язку з автоматизацією польоту можуть виникати ситуації, що вимагають 
монотонного пасивного, але й одночасно пильного спостереження. В такій ситуації у оператора розвивається стан, близький до втоми, що знижує його пильність, i в критичний момент він може не помітити важливого сигналу [46]. При тривалому польоті фізичну втому викликає характерна поза сидячи, дрібні та точно координовані рухи пальців рук [46, 47]. Фізичне навантаження охоплює в основному м'язи спини та попереку, що підтримають робочу позу [45-46]. Розумове навантаження пов'язане передусім зі значним напруженням зору та уваги. При роботі у мобільному пункті керування робота 3 керування БпАК може вестися в умовах, які порушують нормальний хід роботи оператора [41-45]. Заважаючими факторами при цьому можуть бути шум, вібрація, висока або низька температура, зайве або недостатнє освітлення. Крім того, можуть виникати ситуації, коли необхідно виконувати одночасно декілька дій. Відомо, що в таких випадках одна дія може бути «гальмом» по відношенню до іншої, при цьому чим ближче до змісту дії, що виконуються паралельно, тим більше можливість їх взаємного порушення [44-47]. Реальна обстановка може пред’являти високі вимоги до фізичної витривалості, емоційної врівноваженості, здатності до зосередження, об'єму та розподіленню уваги, здатності оператора переключатися з одного завдання на інше. Оскільки помилки, що пов'язані 3 надійністю оператора, можуть призвести до втрати БпАК доцільно проводити професійний добір для цієї професії [45-46]. Метою добору $є$ передбачення двох груп характеристик індивіда: по-перше - його здатність до успішного навчання професії, подруге - ефективність його дій в реальній обстановці з усіма можливими ускладненнями та змінами ситуації. Успішність дій в реальній обстановці неможлива без попередньої доброї підготовки [43-45]. Тому визначення i передбачення «навчальної характеристики» кандидата, легкості засвоєння ним необхідних знань та навичок мають велике практичне значення [32,45-47]. Виходячи 3 цього добір повинен здійснюватися не на основі статичної оцінки загальних та індивідуальних властивостей кандидата, а й на основі виявлення динаміки розвитку даної якості та тенденції ії до підвищення під час навчання [45]. Особи, які не мають достатніх здібностей до певного виду діяльності, не тільки значно довше за інших та з більшими труднощами опановують цю діяльність, але й працюють гірше за інших: частіше роблять помилки та прорахунки, стають винуватцями аварій і в цілому мають меншу надійність в роботі. Тому доцільно витрачати сили, час та кошти саме на добір кандидатів на навчання, а не на навчання людей, віддача від яких буде мінімальною. ДНАОП 0.03-8.06-94 [37]. Перелік робіт, де $\epsilon$ потреба у професійному доборі містить п.10. Роботи, пов'язані 3 нервовоемоційним напруженням (авіадиспетчери, диспетчери по управлінню рухом залізничного транспорту, оператори енергетичних систем) та п.9. Роботи, пов'язані 3 управлінням наземним, підземним, повітряним та водним транспортом. Хоча управління БпАК здійснюється за допомогою дистанційно-пілотованого методу, і БпАК не $є$ транспортним засобом, робота оператора керування БПЛА має ознаки обох названих пунктів. Так, помилкові дії оператора при аварії можуть призвести до втрат при падінні БпАК на населений пункт, при зіткненні 3 літаком або гелікоптером, помилковому використані зброї.

Для мінімізації ризиків, що пов'язані 3 «людським фактором» необхідно виділити основні причини його виникнення:

- недоліки в інженерно-технічному обслуговуванні;

- недосконалість методики підготовки фахівців;

- стан здоров'я та психічний стан зовнішнього пілота під час виконання завдання;

- об’єктивна складність ситуації під час виконання завдання.

Психофізіологічними показниками для професійного добору, згідно з п.9 та 10 [9] є: 1) орієнтація у просторі; 2) реакція на об'єкт, який рухається; 3) увага; 4) швидкість переключення уваги; 5) пам'ять зорова та слухова; 6) емоційна стійкість та почуття тривоги; 7) стійкість до впливу стресів; 8) сенсомоторні реакції; 9) втома; 10) здатність приймати рішення та дії в екстремальних умовах; 11) стійкість до монотонії. Для дослідження цих показників можна використовувати широкий спектр загальних та спеціальних методик, які застосовуються в фізіології праці. В комплекс дослідження повинні бути включені також методики вивчення фізіологічного стану, а саме збудливість та лабільність аналізаторів (зорового та слухового), серцево-судинної системи (ЕКГ, пульс, артеріальний тиск), біохімічні показники крові, треморографія. 
Важливо розробити методичну базу для спеціалістів, які будуть здійснювати професійний відбір зовнішніх пілотів БпАК, з метою систематизувати та уніфікувати основні методики відбору. Вибір методик, деякі з яких є взаємозамінними, залежить від

\section{Висновки}

1. Незважаючи на дослідження окремих питань, проблема комплексної оцінки, 3 позиції системного підходу до професійного здоров'я, у тому числі, умов, причин і економічних наслідків захворюваності експлуатантів, досліджена недостатньо.

2. Виявлені в результаті системноструктурного аналізу чинники, умови i причини, що визначають професійне здоров'я зовнішнього пілота, дозволять скласти комплексне уявлення про його професійне здоров'я, що вкрай необхідно для розробки

\section{Література}

1. Aaronson M., Aslam W., Dyson T., Rauxloh R. Precision strike warfare and international intervention. Oxon, NY.: Routledge, 2015. 264 p.

2. Alimpiev A., Berdnik P., Korolyuk N., Korshets O., Pavlenko M. Selecting a model of unmanned aerial vehicle to accept it for military purposes with regard to expert data Eastern-European Journal of Enterprise Technologies ISSN 1729-3774. - №1/ 9 (85), 2017. - p. 53-60.

3. Afisr Predator. Confessions of a drone veteran: Why using them is more dangerous than the government is telling уои [электронный pecypc] Salon. Tuesday, Sep 16, 2014. URL: http://www.salon.com/2014/09/16/confessions of a drone veteran why using them is more dangerous $t$ han the government is telling you/

4. Arkin W. M. Unmanned: Drones, Data, and the Illusion of Perfect Warfare. NY., Boston, L.: Little, Brown and Co., 2015. $400 \mathrm{p}$.

5. Benjamin M. Drone Warfare: Killing by Remote Control. L., NY.: Verso, 2013. 224 p.

6. Bumiller E. A Day Job Waiting for a Kill Shot a World Away [электронный ресурс] // The New York Times. $\quad 30 . \quad 07.2012 . \quad$ URL: http://www.nytimes.com/2012/07/30/us/dronepilots-waiting-for-a-kill-shot-7000-milesaway.html? $\mathrm{r}=1$ \&ref=todayspaper\&pagewanted=print

7. Calhoun. L. We kill because we can: From soldiering to assassination in the drone age. L.: Zed Books, 2015. 416 p.

8. Chamayou G. Drone Theory. NY.; L.: The New Press, 2015. 304 p.

9. Chappelle W., McDonald K., Thompson B., Swearengen J. Prevalence of High Emotional Distress and Symptoms of Post-Traumatic Stress Disorder in наявності відповідного лабораторного обладнання. Уніфікація методик, що будуть використовуватись різними спеціалістами, забезпечать ідентичність отриманих результатів.

комплексу заходів з оптимізації медичного забезпечення та збереження здоров'я зовнішніх пілотів.

3. Враховуючи те, що у Збройних Силах України з початку 2020 року триває робота стосовно набуття доктринальної взаємосумісності з державами-членами НАТО, актуальним напрямом $\epsilon$ розроблення критеріїв оцінки ступеню придатності операторів безпілотних авіаційних комплексів до роботи за фахом під час проведення лікарсько-льотної експертизи.

U.S. Air Force Active Duty Remotely Piloted Aircraft Operators (2010 USAFSAM Survey Results). Report AFRL-SA-WP-TR-2013-0002. USAF School of Aerospace Medicine Aerospace Medicine Department/FECN 2510 Fifth St. Wright-Patterson AFB, OH 45433-7913. Pp. 1-2. URL: http://www.ncbi.nlm.nih.gov/pubmed/25102551

10. Chappelle W. L., Salinas A., McDonald K. Psychological Health Screening of USAF Remotely Piloted Aircraft (RPA) Operators and Supporting Units // Paper presented at the Symposium on Mental Health and Well-Being Across the Military Spectrum. Bergen, Norway, 12 Apr. 2011. URL: http://www.dtic.mil/cgibin/GetTRDoc?Location=U2\&doc=GetTRDoc.pdf\&AD= ADA582856

11. Chappelle W. L., Goodman T., Reardon. L., Thompson W. An analysis of post-traumatic stress symptoms in United States Air Force drone operators [электронный ресурс] // Journal of Anxiety Disorders. - 2014. - № 28. - P. 480-487. URL: http://digitalcommons.unl.edu/cgi/viewcontent.cgi?a $\underline{\text { rticle }=1045 \& \text { context }=\text { usafresearch }}$

12. Cockburn A. Kill Chain: Drones and the Rise of High-Tech Assassins. L., NY.: Verso, 2015. 368 p.

13. Drew C., Philipps D. As Stress Drives off Drone Operators, Air Force Must Cut Flights [электронный pecypc] // The New York Times. June 16, 2015. URL: https://www.nytimes.com/2015/06/17/us/as-

stress-drives-off-drone-operators-air-force-must-cutflights.html? $\mathrm{r}=0$

14. Freeman C. Armchair killers: life as a drone pilot [электронный ресурс] // The Telegraph. 11 Apr. 2015.

URL:

http://www.telegraph.co.uk/culture/film/film- 
news/11525499/good-kill-drone-pilot-true-

story.html

15. Galliott J. Military Robots: Mapping the Moral Landscape. L., NY.: Routledge, 2016. 280 p.

16. Hickey J. Precision-guided Munitions and Human Suffering in War. Farnham, UK: Ashgate Publishing Ltd, 2012.251 p.

17. Joint Doctrine Note 2/11 (JDN 2/11). The UK approach to unmanned aircraft systems. The Development, Concepts and Doctrine Centre Ministry of Defence Shrivenham SWINDON, Wiltshire, SN6 8RF. 30 March 2011. P. 5-8. URL: https://www.gov.uk/government/uploads/system/u ploads/attachment data/file/33711/20110505JDN 2 11 UAS v2U.pdf

18. Nagy J. E., Kalita S. W., Eaton G. U.S. Air Force Unmanned Aircraft Systems Performance Analyses, Predator Pilot Front End Analysis (FEA Report). SURVIAC-TR-06-203, Feb. 2006. P. 4.

19. Nagy J., Muse K., Eaton G. U.S. Air Force Unmanned Aircraft Systems Performance Analyses: Predator Sensor Operator Front End Analysis (FEA Report). SURVIAC-TR-10-043, 18 Aug. 2006. P.6.

20. Otto J. L., Webber B. J. Mental health diagnoses and counseling among pilots of remotely piloted aircraft in the United States Air Force [электронный pecypc] // Medical Surveillance Monthly Report. 2013 Mar. - 20(3). - P. 3-8.

21. Ouma J. A., Chappelle W. L., Salinas A. Facets of Occupational Burnout among U.S. Air Force Active Duty and National Guard/Reserve MQ-1 Predator and MQ-9 Reaper Operators. Report AFRL-SA-WP-TR-2011-0003 (2011). USAF School of Aerospace Medicine Aerospace Medicine Education 2510 Fifth St. Wright-Patterson AFB, OH 45433-7913. P. 6-7. URL: http://www.dtic.mil/dtic/tr/fulltext/u2/a548103.pdf

22. Petrenko 0. Man-machine symbiosis in aviation: new risks and capabilities in view of information technology expansion Proceedings of the 17-th International Symposium on Aviation Psychology. Dayton (Ohio, USA): Right State University. 2013. P. 116-121.

23. Petrenko 0. Possibilities of using the on-board intelligent voice informing systems in complex flight situations Proceedings of the 18-th International Symposium on Aviation Psychology. - Dayton (Ohio, USA): Right State University. 2015 (accepted for publication).

24. Rogers A., Hill, J. Unmanned: Drone Warfare and Global Security. L.: Pluto Press, 2014. 192 p.

25. Shkurti G. Making Drones Illegal Based on a Wrong Example: The U.S. Dronified Warfare. Turkish Journal of Middle Eastern Studies (Türkiye Ortadoğu Çalışmaları Dergisi). Vol: 3. № 1. 2016. P. 39-74.

26. Strawser B. J. (ed.) Killing by Remote Control: The Ethics of an Unmanned Military. NY: Oxford University Press; 2013. 296 p.
27. The Drone Wars Library [электронный ресурс] The Drone Wars UK. URL: https://dronewars.net/drone-wars-library/

28. Thompson W. T., Lopez N., Hickey P., DaLuz C., Caldwell J. L., Tvaryanas A. P. Effects of Shift Work and Sustained Operations: Operator Performance in Remotely Piloted Aircraft (OPREPAIR). Technical Report HSW-PE-BR-TR-2006-0001. 311th Human Systems Wing, Brooks City-Base, TX, Jan 2006.

29. Tvaryanas A. P., MacPherson G. D. Fatigue in pilots of remotely piloted aircraft before and after shift work adjustment. Aviation, Space, and Environmental Medicine. May 2009. № 80(5). P. 454-461.

30. Walker L. Death From Above: Confessions of a Killer Drone Operator [электронный pecypc] Newsweek. 11/20/15. URL: http://europe.newsweek.com/confessions-lethaldrone-operator-396541?rm=eu

31. Woods C. Sudden Justice: America's Secret Drone Wars. NY.: Oxford University Press: 2015. 416 p

32. Агейко А. Ю., Ісаченко О. О. Підготовка зовнішніх пілотів безпілотних авіаційних комплексів у сучасних умовах. Перспективи розвитку озброєння та військової техніки Сухопутних військ : зб. тез доп. Міжнар. наук.-техн. конф., Львів, 17-18 трав. 2018 р. Міноборони, Нац. акад. сухопутних військ ім. гетьмана Петра Сагайдачного. Л. : НАСВ, 2018. С. 83-84. 711474 В 623

33. Герасименко В.В., Василенко О.А. Аналіз застосування безпілотних літальних апаратів в збройних конфліктах сучасності. Збірник наукових пращь НУОУ «Труди університету» 2020. № 6 (162) Інв.№ 49157.

34. Застосування безпілотних літальних апаратів у воєнних конфліктах сучасності : [монографія] [Горошко О. О., Зіатдінов Ю. К., Ільяшов О. А. та ін.] ; під ред. С. П. Мосова. К. : КиєвоМогилян. акад., 2013. 248 с. - (Бібліотека воєнної історії). Р 345931623

35. Игнатьев О.В. БЛА: состояние и перспективы их использования в интересах НАТО. Зарубежное военное обозрение. 2010. № 12. С. 21-27.

36. Казакова А. Безпілотники АТО: реалії та перспективи. Авіатор України. 2015. № 1. С. 6. $\mathrm{P} / 2339$.

37. Класифікатор професій ДК 003:2010. - Режим доступа: http://www.dk003:2010.

38. Класифікація безпілотних літальних апаратів. О. І. Тимочко, Д. Ю. Голубничий, В. Ф. Третяк, I. В. Рубан. Системи озброєння і військова техніка. 2007. № 1. С. 61-66. Бібліогр.: с. 66 (3 назви). $\mathrm{P} / 1903$

39. Ломов Б.Ф. Методологические и теоретические проблемы психологии. М.: Наука, 1984. 411с. 9. ДНАОП 0.03-8.06-94. Перелік робіт, де $\epsilon$ потреба у професійному доборі. Режим доступа: http://zakon3.rada.gov.ua/laws/show/ru/z0018-95 
40. Медведєв Г.А. Інтеграція безпілотних авіаційних комплексів до загального повітряного простору. Світовий досвід та основні завдання. Збірник наукових праџь ДНДІА. 2015. № 11 (18). С. 25-29.

41. Національний стандарт ДСТУ В 7371:2013 "Техніка авіаційна військової призначеності. Апарати літальні безпілотні. Основні терміни, визначення понять і класифікація". К.: Мінекономрозвитку. 2014. 11 с.

42. Павлушенко, М.Беспилотные летательные аппараты: история, применение, угроза распространения и перспективы развития, И. Макаренко. Москва, 2005. 612 с.

43. Прокофьев С. Подготовка операторов беспилотных летательных аппаратов. Зарубежное военное обозрение. 2004. № 8. С. 37-43. Р/689.

\section{References}

1. Aaronson, M., \& Rauxloh, R. (2015). Precision strike warfare and international intervention. Oxon, NY.: Routledge.

2. Alimpiev, A., \& Pavlenko, M. (2017). Selecting a model of unmanned aerial vehicle to accept it for military purposes with regard to expert data EasternEuropean. Journal of Enterprise Technologies, №1, 9 (85), 53-60.

3. Afisr, Predator. (2014). Confessions of a drone veteran: Why using them is more dangerous than the government is telling you. Salon, Tuesday, Sep 16 http://www.salon.com/2014/09/16/confessions of a drone veteran why using them is more dangerous $t$ han the government is telling_you/

4. Arkin, W. M. (2015). Unmanned: Drones, Data, and the Illusion of Perfect Warfare. NY., Boston, L.: Little, Brown and Co.

5. Benjamin, M. (2013). Drone Warfare: Killing by Remote Control. L., NY.: Verso.

6. Bumiller, E. A. (2012). Day Job Waiting for a Kill Shot a World Away. The New York Times. (30.07.). http://www.nytimes.com/2012/07/30/us/dronepilots-waiting-for-a-kill-shot-7000-milesaway.html? $\mathrm{r}=1$ \&ref=todayspaper\&pagewanted=print

7. Calhoun, L. (2015). We kill because we can: From soldiering to assassination in the drone age. L.: Zed Books.

8. Chamayou, G. (2015). Drone Theory. NY.; L.: The New Press.

9. Chappelle, W., \& Swearengen, J. (2014). Symptoms of psychological distress and post-traumatic stress disorder in United States Air Force "drone" operators. MilMed, Aug;179(8 Suppl):63-70. doi: 10.7205/MILMED-D-13-00501.

http://www.ncbi.nlm.nih.gov/pubmed/25102551

10. Chappelle, W. L., \& McDonald, K. (2011). Psychological Health Screening of USAF Remotely Piloted Aircraft (RPA) Operators and Supporting Units. Paper presented at the Symposium on Mental Health and Well-Being Across the Military Spectrum. Bergen, Norway,
44. Прохоров С. Подготовка операторов беспилотных летательных аппаратов. Зарубежное военное обозрение. 2004. № 8. С. 37-43.

45. Ударцева Т. Є. Доцільність проведення професійного добору операторів керування безпілотними літальними апаратами. Системи озброєння і військова техника. 2016. № 1 (45). С. 186-189.

46. Ударцева Т. Працездатність авіаційних спеціалістів: монограф. К.: Славутич-Дельфін, 2014. $108 \mathrm{c.}$

47. Харченко О.В., Богославець С.О., Коцуренко Ю.В. Комплексний аналіз перспектив розвитку військової безпілотної авіації у збройних силах провідних країн світу. Наука і оборона. 2013. №1. С. 51-57.

http://www.dtic.mil/cgibin/GetTRDoc?Location=U2\& doc $=$ GetTRDoc.pdf\&AD=ADA582856

11. Chappelle, W. L., \& Thompson, W. (2014). An analysis of post-traumatic stress symptoms in United States Air Force drone operators. Journal of Anxiety Disorders. $\quad$ (№ 28. pp.480-487). http://digitalcommons.unl.edu/cgi/viewcontent.cgi?a rticle $=1045 \&$ context=usafresearch

12. Cockburn, A. (2015). Kill Chain: Drones and the Rise of High-Tech Assassins. L., NY.: Verso.

13. Drew, C., Philipps, D. (2015). As Stress Drives off Drone Operators, Air Force Must Cut Flights. The New York Times. June 16.

https://www.nytimes.com/2015/06/17/us/as-

stress-drives-off-drone-operators-air-force-must-cutflights.html? $\mathrm{r}=0$

14. Freeman, C. (2015). Armchair killers: life as a drone pilot. The Telegraph. 11 Apr. http://www.telegraph.co.uk/culture/film/filmnews/11525499/good-kill-drone-pilot-truestory.html

15. Galliott, J. (2016). Military Robots: Mapping the Moral Landscape. L., NY.: Routledge.

16. Hickey, J. (2012). Precision-guided Munitions and Human Suffering in War. Farnham, UK: Ashgate Publishing Ltd.

17. Joint Doctrine Note 2/11 (JDN 2/11). (2011, 30 March). The UK approach to unmanned aircraft systems. The Development, Concepts and Doctrine Centre Ministry of Defence Shrivenham SWINDON, Wiltshire, SN6 8RF.

https://www.gov.uk/government/uploads/system Luploads/attachment data/file/33711/20110505JDN 211 UAS v2U.pdf

18. Nagy, J. E., \& Eaton, G. (2006). U.S. Air Force Unmanned Aircraft Systems Performance Analyses, Predator Pilot Front End Analysis (FEA Report). SURVIAC-TR-06-203, Feb. (4).

19. Nagy, J., \& Eaton, G. (2006). U.S. Air Force Unmanned Aircraft Systems Performance Analyses: Predator Sensor Operator Front End Analysis (FEA Report). SURVIAC-TR-10-043, 18 Aug. (6). 
20. Otto, J. L., Webber, B. J. (2013). Mental health diagnoses and counseling among pilots of remotely piloted aircraft in the United States Air Force. Medical Surveillance Monthly Report, 20(3), 3-8.

21. Ouma, J. A., \& Salinas, A. (2011). Facets of Occupational Burnout among U.S. Air Force Active Duty and National Guard/Reserve MQ-1 Predator and MQ-9 Reaper Operators. Report AFRL-SA-WP-TR-2011-0003 USAF School of Aerospace Medicine Aerospace Medicine Education 2510 Fifth St. Wright-Patterson AFB, OH 45433-7913.

http://www.dtic.mil/dtic/tr/fulltext/u2/a548103.pdf

22. Petrenko, O. (2013). Man-machine symbiosis in aviation: new risks and capabilities in view of information technology expansion. Proceedings of the 17-th International Symposium on Aviation Psychology. Dayton (Ohio, USA): Right State University. 116-121.

23. Petrenko, O. (2015). Possibilities of using the onboard intelligent voice informing systems in complex flight situations. Proceedings of the 18-th International Symposium on Aviation Psychology. Dayton (Ohio, USA): Right State University. 2015.

24. Rogers, A., Hill, J. (2014). Unmanned: Drone Warfare and Global Security. L.: Pluto Press.

25. Shkurti, G. (2016). Making Drones Illegal Based on a Wrong Example: The U.S. Dronified Warfare. Turkish Journal of Middle Eastern Studies (Türkiye Ortadoğu Çalışmaları Dergisi). (Vol: 3. № 1. 39-74).

26. Strawser, B. J. (ed.) (2013). Killing by Remote Control: The Ethics of an Unmanned Military. NY: Oxford University Press.

27. The Drone Wars Library. (2020). The Drone Wars UK. https://dronewars.net/drone-wars-library/

28. Thompson, W. T., \& Tvaryanas, A. P. (2006). Effects of Shift Work and Sustained Operations: Operator Performance in Remotely Piloted Aircraft (OPREPAIR). Technical Report HSW-PE-BR-TR-20060001. 311th Human Systems Wing, Brooks City-Base, TX.

29. Tvaryanas, A. P., MacPherson, G. D. (2009). Fatigue in pilots of remotely piloted aircraft before and after shift work adjustment. Aviation, Space, and Environmental Medicine. № 80(5). 454-461.

30. Walker, L. (2015). Death From Above: Confessions of a Killer Drone Operator. Newsweek. (11/20). http://europe.newsweek.com/confessionslethal-drone-operator-396541? rm=eu

31. Woods, C. (2015). Sudden Justice: America's Secret Drone Wars. NY.: Oxford University Press.

32. Ageyko, A.Yu., Isachenko, O.O. (2018). Preparation of external pilots of unmanned aerial vehicles in modern conditions. Ministry of Defense, Nat. acad. ground forces. Hetman Peter Sagaidachny. L.: NASV. (83-84. 711474 B 623).

33. Herasymenko, V.V., Vasylenko, O.A. (2020). Analysis of the use of unmanned aerial vehicles in the armed conflicts of today. Zbirnyk naukovykh prats NUOU «Trudy Universytetu». (№ 6 (162) Inv. № 49157). [In Ukrainian].

34. Goroshko, 0.0, Ziatdinov, Yu. K., \& Ilyashov, O.A. (2013). Application of unmanned aerial vehicles in modern military conflicts. Kyiv: Kyiv-Mohyla. Acad. [In Ukrainian].

35. Ignatiev, O.V. (2010). BLA: the state and prospects of their use in the interests of NATO. Zarubezhnoe Voennoe Obozrenye, № 12, 21-27. [In Ukrainian].

36. Kazakova, A. (2015). ATO drones: realities and prospects. Aviator Ukrainy, № 16. [In Ukrainian].

37. Classifier of professions DK 003: 2010. (2010). http: //www.dk003: 2010. [In Ukrainian].

38. Tymochko, O.I., Golubnychy, D.Yu., \& Ruban, I.V. (2007). Classification of unmanned aerial vehicles. Systemy ozbroiennia i viiskova tekhnika. № 1, 61-66. [In Ukrainian].

39. Lomov, B.F. (1984). Methodological and theoretical problems of psychology. M.: Nauka. http://zakon3.rada.gov.ua/laws/show/ru/z0018-95

[In Russian].

40. Medvedev, G.A. (2015). Integration of unmanned aerial vehicles into the common airspace. World experience and main tasks. Zbirnyk naukovykh prats DNDIA. (№ 11 (18). 25-29). [In Ukrainian].

41. National standard DSTU B 7371: 2013 (2014). "Military aviation equipment. Unmanned aerial vehicles. Basic terms, definitions and classification". Kyiv: Ministry of Economic Development. [In Ukrainian].

42. Pavlushenko, M., \& Makarenko, I. (2005). Unmanned aerial vehicles: history, application, threat of spread and prospects of development. Moscow. [In Russian].

43. Prokofiev, S. (2004). Training of operators of unmanned aerial vehicles. Zarubezhnoe obozrenye. (№ 8. 37-43). [In Russian].

44. Prokofiev, S. (2004). Training of operators of unmanned aerial vehicles. Zarubezhnoe obozrenye. (№ 8. 37-43). [In Russian].

45. Udartseva, T.E. (2016). The feasibility of professional selection of control operators for unmanned aerial vehicles. Systemy ozbroiennia $i$ viiskova tekhnyka. (№ 1 (45). 186-189). [In Ukrainian].

46. Udartseva, T. (2014). Working capacity of aviation specialists: monograph. K .: Slavutych-Delfin. [In Ukrainian].

47. Kharchenko, O.V., \& Kotsurenko, Yu.V. (2013). Comprehensive analysis of the prospects for the development of military unmanned aerial vehicles in the armed forces of the world's leading countries. Nauka i oborona. (№1. 51-57). [In Ukrainian]. 


\title{
АНАЛИЗ ПРОБЛЕМЫ ОПТИМИЗАЦИИ КРИТЕРИЕВ ОЦЕНКИ СТЕПЕНИ ПРИГОДНОСТИ ВНЕШНИХ ПИЛОТОВ БЕСПИЛОТНЫХ АВИАЦИОННЫХ КОМПЛЕКСОВ К РАБОТЕ ПО СПЕЦИАЛЬНОСТИ ПРИ ПРОВЕДЕНИИ ВРАЧЕБНО-ЛЕТНОЙ ЭКСПЕРТИЗЫ
}

\author{
А.Н. Галушка' ${ }^{1}$ Л.В. Рущак², В.В. Герасименкоํㅜ О.В. Числицкая ${ }^{2}$ \\ ${ }^{1}$ Командование Медицинских сил Вооруженных Сил Украины, г.Киев, Украина \\ 2 Украинская военно-медицинская академия, г.Киев, Украина \\ ${ }^{3}$ Национальный университет обороны Украины имени Ивана Черняховского, г.Киев, Украина
}

\begin{abstract}
Вступление. Важное место в надежности внешнего пилота БпАК принадлежит психофизиологической подготовке, поскольку при эксплуатации современной техники остро встает вопрос психофизиологического барьера, причины которого лежат в психофизиологических возможностях и факторе времени, выделяемого на принятие решения. Выше сказанное указывает на необходимость поиска новых методических подходов к адекватному использования человеческого потенциала учитывая специфику труда внешнего пилота БпАК.
\end{abstract}

Цель. Анализ проблемы оптимизации критериев оценки степени пригодности внешних пилотов беспилотных авиационных комплексов к работе по специальности при проведении врачебно-летной экспертизы.

Материалы и методы. Библиосемантический, исторический, структурно-логический и системного подхода.

Результаты. В Украине до сих пор использование БпАК носило ограниченный характер. К сожалению, до сих пор не существует государственной программы разработки и эксплуатации БпАК, поэтому нет общей стратегии развития беспилотной авиации, возникает определенная путаница в технической и разрешительной документации, терминологии, нерешенными остаются проблемы подготовки и отбора операторов. Сложность применяемых БпАК и разнообразие задач, реализуемых с их помощью, определяют максимально широкий спектр требований $\kappa$ профессиональной подготовленности операторов, осуществляющих управление такими авиационными комплексами. Практика показывает, что обеспечение надежности деятельности операторов БпАК и успешности выполнения ими задач по назначению должен реализовываться начиная с этапа профессионального отбора кандидатов на обучение по соответствующей спещиальности. Именно качественный научно обоснованный и методично обеспечен профессиональный отбор позволит избежать значительных финансовых и временных затрат на подготовку профессионально не пригодных специалистов, уменьшить потери дорогостоящих БпАК и не допустить создания прецедентов опасностей от непрофессиональной эксплуатации приведенной техники. Все указанное выше актуализирует необходимость качественного осуществления профессионального отбора кандидатов на должности операторов (внешних пилотов) беспилотных авиационных комплексов тактических классов для нужд ВС Украины, НГУ и других силовых структур нашей страны. Важным условием профотбора и анализа эффективности специальной подготовки является изучение психологической готовности, а именно: индивидуально-психологических и психофизиологических особенностей операторов БпАК. Таким образом, одним из первостепенных задач в подготовке специалистов данной отрасли является разработка диагностического инструментария изучения готовности к осуществлению профессиональной деятельности.

Выводы. Несмотря на исследование отдельных вопросов, проблема комплексной оценки, с позиции системного подхода к профессиональному здоровья, в том числе, условий, причин и экономических последствий заболеваемости эксплуатантов, исследована недостаточно. Выявленные в результате системно-структурного анализа факторы, условия и причины, определяющие профессиональное здоровье внешнего пилота, позволят составить комплексное представление о его профессиональное здоровье, что крайне необходимо для разработки комплекса мероприятий по оптимизации медицинского обеспечения и сохранения здоровья внешних пилотов. Учитывая, что в Вооруженных Силах Украины по началу 2020 года продолжается работа по приобретению доктринальной совместимости с государствами-членами НАТО, актуальным направлением является разработка критериев оценки степени пригодности операторов беспилотных авиационных комплексов к работе по специальности при проведении врачебно-летной экспертизы.

Ключевые слова: беспилотный авиационный комплекс, внешний пилот, профессиональная пригодность. 


\title{
ANALYSIS OF THE CRITERIA-OPTIMIZATION PROBLEM IN EVALUATION OF THE SUITABILITY DEGREE DURING AVIATION MEDICAL EXAMINATION OF UNMANNED AVIATION COMPLEXES' PILOTS TO PERFORM THEIR DUTIES
}

\author{
A.M. Halushka1, L.V. Rushchak², V.V. Herasymenko³ , 0.V. Chyslitska² \\ ${ }^{1}$ Medical Forces Command of the Armed Forces of Ukraine, Kyiv, Ukraine \\ ${ }^{2}$ Ukrainian Military Medical Academy, Kyiv, Ukraine \\ ${ }^{3}$ National Defence University of Ukraine named after Ivan Cherniakhovskyi, Kyiv, Ukraine
}

Introduction. An important place in the reliability of the unmanned aviation complexes (UAC) pilot belongs to psychophysiological training, since during the operation of modern technology acutely arises issues of a psychophysiological barrier, the reasons for which lies in psychophysiological capabilities and time factors released to decision making. This indicates the need to find new methodological approaches to adequate use of human potential, taking into account the specifics of the external pilot of UAC.

Purpose. Compregensive analysis of the criteria-optimization problem in evaluation of the suitability degree during aviation medical examination of unmanned aviation complexes' pilots to perform their duties unfailingly .

Materials and methods. Bibysmantical, historical, structual-logical and system approach have been used.

Results. In Ukraine, compere with other countries, the use of UAC has a limited character. Unfortunately, there is still no state program for the development and operation of UAC so there is no general strategy for the development of unmanned aviation, there is a certain confusion in the technical and permit documentation, terminology, the problems of preparation and selection of operators remain unsolved. The complexity of UAC using and a variety of tasks implemented with their help, determine the widest range of requirements for professional preparedness of operators that control such aviation complexes. Practice shows that ensuring the reliability of operators of UAC and the success of their purpose by appointment should be implemented from the stage of professional selection of candidates for training in the relevant specialty. It is a high-quality scientifically substantiated and methodically secured occupational selection will allow to avoid significant financial and temporal costs for training professionally non-suitable specialists, reduce the loss of high-speed UAC and prevent the creation of precedents of dangers from unprofessional operation of the given technique. All of the above updates the necessity of qualitative implementation of occupational selection of candidates for positions of operators (external pilots) of unmanned aviation complexes of tactical classes for the needs of the Armed Forces of Ukraine and other power structures of our country. An important condition for the proof and analysis of the effectiveness of special training is the study of psychological readiness, namely: individual-psychological and psychophysiological features of UAC operators. Thus, one of the primary tasks in the preparation of specialists in this engineering is the development of a diagnostic tool for the study of readiness for professional activity.

Conclusions. Despite the study of individual issues, the problem of a comprehensive assessment, from the position of a systematic approach to occupational health, including conditions, reasons and economic consequences of the incidence of operators, was investigated. As a result of system-structural analysis it was found factors, conditions and reasons that determine the occupational health of the external pilot will allow comprehensive representation of its health, which is extremely necessary to develop a set of measures to optimize medical support and maintaining the healthy external pilots. Taking into account that since the beginning of 2020 in the Armed Forces of Ukraine the work on the acquisition of doctrinal interoperability with NATO member states continues to develop criteria for evaluation of the suitability degree during aviation medical examination of unmanned aviation complexes' pilots to perform their duties.

Key words: unmanned aviation complex, external pilot, professional suitability.

Конфлікт інтересів: відсутній.

Conflicts of interest: authors have no conflict of interest to declare.

\section{Відомості про авторів:}

Галушка А.М. E,F - полковник медичної служби, доктор медичних наук, професор, начальник штабузаступник командувача Медичних сил Збройних Сил України, м. Київ https://orcid.org/0000-0003-3530$\underline{0946}$.

Рущак Л.В. A,B,C,D,E - кандидат біологічних наук, доцент, провідний науковий співробітник Науководослідного інституту проблем військової медицини Української військово-медичної академії, м. Київ Еmail: zolotaya@ua.fm, https://orcid.org/0000-0003-4653-1002.

Герасименко В.В. А,С,Е - полковник, кандидат військових наук, докторант кафедри авіації інституту авіації та протиповітряної оборони Національного університету оборони України імені Івана Черняховського, м. Київ. E-mail: gera410@ukr.net, https://orcid.org/0000-0003-2014-7408

Числіцька О.B. B,D - кандидат психологічних наук, старший науковий співробітник науковоорганізаційного відділення Української військово-медичної академії, м. Київ. E-mail: olgachisel@gmail.com, https://orcid.org/0000-0003-0416-4961 
$A$ - концепція та дизайн дослідження; $B$ - збір даних; $C$ - аналіз та інтерпретація даних;

$D$ - написання статті; $E$ - редагування статті; F - остаточне затвердження статті.

Сведения об авторах:

Галушка А.М. - полковник медицинской службы, доктор медицинских наук, профессор, начальник штаба- заместитель командующего Медицинских сил Вооруженных Сил Украины, г. Киев.

Рущак Л.В. - кандидат биологических наук, доцент, ведущий научный сотрудник Научноисследовательского института проблем военной медицины Украинской военно-медицинской академии, г. Киев.

Герасименко В.В. - полковник, кандидат военных наук, докторант кафедры авиации института авиации и противовоздушной обороны Национального университета обороны Украины имени Ивана Черняховского, г. Киев.

Числицкая О.В. - кандидат психологических наук, старший научный сотрудник научноорганизационного отделения Украинской военно-медицинской академии., г. Киев.

\section{Information about authors:}

Halushka A.M. E,F - Col. MS, Doctor of Medical Sciences, Professor, Chief of Staff - Deputy Commander of the Medical Forces of the Armed Forces of Ukraine. https://orcid.org/0000-0003-3530-0946, Kyiv.

Rushchak L.V. A,B,C,D,E - PhD Biol., Associate Professor, Research Institute of Military Medicine of the Ukrainian Military Medical Academy. Email: zolotaya@ua.fm https://orcid.org/0000-0003-4653-1002 Kyiv.

Herasymenko V.V. A,C,E - Col., PhD in Military Science, Institute of Aviation and Air Defence, The National Defence University of Ukraine named after Ivan Cherniakhovskyi, Email: gera410@ukr.net https://orcid.org/0000-0003-2014-7408, Kyiv.

Chyslitska O.V. B,D - PhD Psychol. Sci., Senior Researcher of the Scientific and Organizational Department of the Ukrainian Military Medical Academy, Email: olgachisel@gmail.com https://orcid.org/0000-0003-04164961, Kyiv.

$A$ - research concept and design; $B$ - collection and/or assembly of data; $C$ - data analysis and interpretation; $D$ - writing the article; $E$ - critical revision of the article; $F$ - final approval of the article.

Адреса для листування: вул. Московська, 45/1, буд. 33, м. Київ 01015 